\title{
Essential Inorganic lons in Milk-Based Drinks: Evaluation of Bioaccessibility
}

\author{
Mirla Cidade ${ }^{1}$, Solange Cadore ${ }^{2}$ and Emanueli do Nascimento da Silva ${ }^{2 *}$ \\ ${ }^{1}$ Chemistry Department, Federal University of Roraima, Boa Vista, RR, Brazil \\ ${ }^{2}$ Institute of Chemistry, University of Campinas, Campinas, SP, Brazil
}

\section{Graphical Abstract}

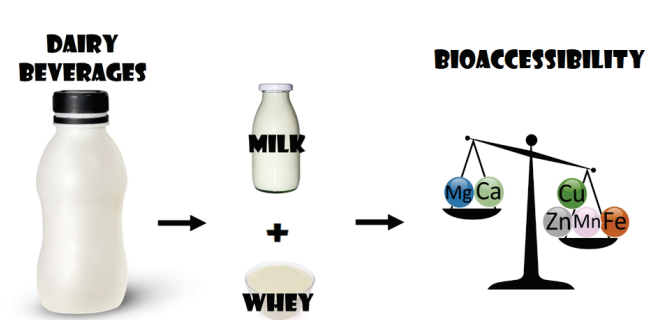

The determination of the bioaccessible fractions of $\mathrm{Co}, \mathrm{Cu}, \mathrm{Mo}$, $\mathrm{Mn}, \mathrm{Fe}, \mathrm{Zn}, \mathrm{Mg}$ and $\mathrm{Ca}$ in milk-based drinks (dairy beverages) was carried out using in vitro digestion and quantification by ICP OES. Microwave assisted mineralization was used for sample preparation and the method allowed recoveries between $90-110 \%$ for all the elements, considering three different levels of analytes addition, with relative standard deviations (RSD) below $10 \%$. The total concentration of $\mathrm{Ca}$ determined by the present method was in good agreement with the value declared by the manufacturer while Co was the only element that was below the limit of quantification (LOQ). The bioaccessible fractions for $\mathrm{Ca}$ and $\mathrm{Mg}$ were approximately $100 \%$ while for $\mathrm{Cu}, \mathrm{Zn}, \mathrm{Mn}$ and $\mathrm{Fe}$ the bioaccessibility values were $56,48,46$, and $29 \%$, respectively, and for Co and Mo the values were below the LOQ. Additionally, it was noticed that the bioaccessibility of these elements may vary according to the sample composition.

Keywords: bioaccessibility, milk-based drink, dairy beverages, in vitro digestion, ICP OES

\section{INTRODUCTION}

In Brazil, dairy beverages are defined as a "milky product resulting from the mixture of milk (in natura, pasteurized, sterilized, reconstituted, UHT, concentrated, powder, integral, semi-skimmed or skimmed) and whey (liquid, powder and concentrated), with addition or not of vegetal fat, fermented milk and other dairy products". The amount of milk on the composition of these beverages should not be less than $51 \%$ and, often, fruits or chocolate are added, among other components. About $50 \%$ of this drink is consumed over breakfast. Dairy beverages are in the $4^{\text {th }}$ position of most consumed liquid foods, accounting for $12 \%$ of the total daily volume of non-alcoholic liquids. In the last years, this type of beverages has been chosen as a nutritional food to be consumed for children, seniors and also for people who choose a healthy life style [1].

Whey is a by-product from cheese manufacture, representing about 85 to $95 \%$ of the total volume of milk, depending on the type of cheese produced, hard, semi-hard or soft [2]. It retains about $55 \%$ of the nutrients present in milk $[3,4]$ and was considered for a long time as a residue by dairy industries being often discarded. However, whey has been used as a raw material in the manufacture of various products due to its nutritional characteristics $[2,5]$.

The use of whey to produce dairy beverages contributes to minimize environmental pollution problems, as well as facilitating their consumption. Some authors have reported that $50 \%$ of world whey production is treated and processed into different food products, with half of this total being used in the liquid form $[6,7]$. This usage is mainly in fermented milk beverage that represents $25 \%$ of the total market of yogurts in Brazil, which became a very promising market [8].

Considering the large consumption of this type of food and the population growth, better food control is needed, especially those destined for children. Monitoring of the amount of proteins, calories, vitamins and also of inorganic nutrients is necessary since deficiencies of nutrients can alter the activities of the enzymatic and metabolic functions increasing public health expenditures [9]. The food composition is a reasonable indication of its nutritional value; however, it is not enough for a complete characterization considering the 


\section{Article}

nutritional aspect, because there are few nutrients that are totally available after ingestion. Hence, determining the bioaccessibility and the bioavailability of minerals in diets is important since these terms are associated with the establishment of the intake recommendations of these elements in accordance with the needs of individuals. Thus, this type of studies is used to obtain information on the behavior of the nutrients during the digestion/absorption process [10].

Considering nutritional aspects, bioavailability is the fraction of the nutrient that is available for using in physiological functions or to be stored. This means that bioavailability refers to the fraction that passes through the cell barrier and reaches the bloodstream. It is important to emphasize that bioavailability includes bioaccessibility, which is the fraction of nutrient that is soluble during the digestion and can be absorbed by the body [11-14].

The interest in bioaccessibility of nutrients has been growing in recent years, and many of them have been evaluated in different kinds of food like baby food [15,16], lettuce [17,18], beef [19], coffee [20], berries [21] and cheese [22], using different experimental models of in vitro digestion for obtaining data. Some important issues have been studied such as the influence of the food structures and the synergism or antagonism between food components, as well as the standardization of the methods to evaluate the soluble fractions of a food during the gastrointestinal digestion.

Regarding the influence of the food structures of dairy foods, several authors described that the amount of nutrient released during the digestion depends on the food structure. Lamothe et al. studied different dairy matrices such as milk, yogurt, and cheese and observed that for cheeses, greater fatty acid release could not be related to faster matrix disintegration, suggesting that the lipid droplet size dispersion was more important than matrix breakdown for the modulation of lipid digestion kinetics [23]. Rinaldi et al. evaluated two liquid dairy matrices (pasteurized and sterilized milks) and one semi-liquid dairy matrix (stirred-yogurt), concluding that the severity of milk's heat treatment influences the kinetics of protein digestion, mainly during the gastric phase [24]. Mulet-Cabero et al. investigated a semi-solid meal comprised a mixture of cheese and yogurt and a liquid meal, an oil in water emulsion stabilized by milk proteins, and noted that the semi-solid sample generated higher nutrient released into the small intestine at an early stage of digestion whereas nutrient accessibility from liquid sample was delayed due to the formation of a cream layer in the gastric phase [25].

Considering the standardization aspect, a standard model was proposed by Minekus et al. based on three sequential extraction steps, i.e., salivary, gastric and intestinal digestion [26]. The main characteristics of the general in vitro methods are: digestion temperature, incubation time, agitation, concentration and composition of enzymes (enzymes from saliva, gastric juice, duodenal juice and bile salts). These characteristics depend on the person involved, the age, the mental health, the time of day that the food is consumed, the type and amount of food consumed and other components from the food consumed [11,27, 28]. In vitro methods have been proposed as an alternative to in vivo methods to estimate the bioavailability of elements in food [29].

Considering all these aspects, the objective of this work was to determine the soluble fraction (bioaccessible content) of micro ( $\mathrm{Co}, \mathrm{Cu}, \mathrm{Mo}, \mathrm{Mn}, \mathrm{Fe}$ and $\mathrm{Zn}$ ) and macro-constituents ( $\mathrm{Mg}$ and $\mathrm{Ca}$ ) present in milk-based drinks using in vitro digestion with detection by ICP OES.

\section{MATERIALS AND METHODS}

\section{Instruments, Reagents and Solutions}

For sample treatment the following equipment were used: closed vessel microwave oven, model ETHOS, from Milestone (Sorisole, Italy); water bath, Quimis, model Q226M1 (Diadema, Brazil); centrifuge, Quimis, model Q222T204 (Diadema, Brazil). The pH measurements were carried out with a pH-meter (Hanna Instruments, model pH200, São Paulo, Brazil) equipped with a combined glass electrode (silver/silver chloride). 
For the determination of the analytes an inductively coupled plasma optical emission spectrometer (ICP OES, Perkin Elmer, Optima 3000DV, Norwalk, CT, USA) equipped with a peristaltic pump, a cross flow nebulizer coupled to a Ryton double pass spray chamber (Scott type) and a ceramic central torch tube injector with an internal diameter of $2.0 \mathrm{~mm}$ was used. This instrument operates sequentially in either radial or axial torch configurations and has a solid state segmented array charge coupled device (SCD) detector. The argon gas (White Martins, São Paulo, Brazil) used for the analyses was $99.996 \%$ pure. The ICP OES parameters optimized for analysis included the following: a radio frequency power of $1300 \mathrm{~W}$, a plasma argon flow rate of $15 \mathrm{~L} \mathrm{~min}^{-1}$, an auxiliary argon flow rate of $0.5 \mathrm{~L} \mathrm{~min} \mathrm{~m}^{-1}$, a nebulization gas flow rate of $0.8 \mathrm{~L}$ $\mathrm{min}^{-1}$, sample flow rate of $1.0 \mathrm{~mL} \mathrm{~min}^{-1}$, radial observation height of $15 \mathrm{~mm}$ (for $\mathrm{Ca}, \mathrm{Co}, \mathrm{Cu}, \mathrm{Fe}, \mathrm{Mg}, \mathrm{Mo}$ ) and 30 seconds of reading time. The analytes studied included the following: Ca (317.933 nm), Co (228.616 nm), $\mathrm{Cu}(324.752 \mathrm{~nm}), \mathrm{Fe}(238.204 \mathrm{~nm}), \mathrm{Mg}(285.231 \mathrm{~nm}), \mathrm{Mn}(257.610 \mathrm{~nm}$ axial view), Mo (202.031 nm) (213.857 $\mathrm{nm}$ axial view).

All reagents used were of analytical grade and the deionized water used was produced by a Milli-Q system (Millipore, Bedford, MA, USA), showing conductivity of $18 \mathrm{M} \Omega \mathrm{cm}$. The materials, polyethylene bottles and glasses, were previously soaked in $10 \%(\mathrm{v} / \mathrm{v}) \mathrm{HNO}_{3}$ (Merck, Darmstadt, Germany) for at least $12 \mathrm{~h}$ and rinsed with ultrapure water before use.

The standard solutions used for the analytical calibration curves were obtained from $1000 \mathrm{mg} \mathrm{L}^{-1} \mathrm{stock}$ solutions of $\mathrm{Co}, \mathrm{Cu}, \mathrm{Fe}, \mathrm{Mn}, \mathrm{Mo}, \mathrm{Zn}$ and from $4000 \mathrm{mg} \mathrm{L}^{-1}$ stock solutions for $\mathrm{Ca}$ and $\mathrm{Mg}$ (all standards were Merck, Darmstadt, Germany), prepared in $1 \%(\mathrm{v} / \mathrm{v}) \mathrm{HNO}_{3}$. Concentrated $\mathrm{HNO}_{3}$ (Merck), concentrated $\mathrm{H}_{2} \mathrm{O}_{2}$ (Merck), concentrated $\mathrm{HCl}$ (Merck), $\mathrm{NaHCO}_{3}$ (Merck), $\mathrm{NaOH}$ (Synth, Diadema, Brazil), pancreatin (Acros Organics, Morris Plains, USA), bile salt (Sigma Chemical Co., Saint Louis, USA), and pepsin (Acros Organics) were also used.

Ten samples (designed as MD1, MD2,..., MD10) of milk-based drinks, from seven different manufacturers $(A, B, \ldots, G)$ were purchased in local supermarkets of Campinas, SP, Brazil.

\section{Microwave-assisted digestion}

For total analysis, the samples were submitted to microwave-assisted oxidative digestion based on a procedure recommended by the microwave oven manufacturer (to bovine milk). Approximately $1 \mathrm{~g}$ of each sample was weighed and transferred to closed microwave vials (Teflon ${ }^{\circledR}$ ) and then $3 \mathrm{~mL}$ of concentrated $\mathrm{HNO}_{3}, 1 \mathrm{~mL}$ of concentrated $\mathrm{H}_{2} \mathrm{O}_{2}$ and $5 \mathrm{~mL}$ of deionized water were added. The final mixture was weighed (acidity $\sim 30 \%$ ) in order to express the final results as $\mathrm{w} / \mathrm{w}$, and then submitted to the heating program described in Table I. Each procedure was carried out in triplicate.

Table I. Heating program of microwave oven

\begin{tabular}{lcc}
\hline Stage & Time $(\boldsymbol{m i n})$ & Temperature $\left({ }^{\circ} \mathbf{C}\right)$ \\
\hline 1 (ramp) & 3 & 80 \\
2 (hold) & 2 & 80 \\
3 (ramp) & 4 & 120 \\
4 (hold) & 5 & 120 \\
5 (ramp) & 7 & 200 \\
6 (hold) & 25 & 200 \\
\hline
\end{tabular}

The evaluation of method efficiency was carried out through addition and recovery of the analytes experiments, at three different concentration levels, as described in Table II. 


\section{Article}

Table II. Concentration ( $\left.\mathrm{mg} \mathrm{L}^{-1}\right)$ of the analytes added to MD1 sample

\begin{tabular}{lccc}
\hline Elements & Level $\mathbf{1}$ & Level $\mathbf{2}$ & Level $\mathbf{3}$ \\
\hline $\mathrm{Co}, \mathrm{Mo}, \mathrm{Mn}, \mathrm{Cu}$ & 0.05 & 0.1 & 0.4 \\
$\mathrm{Fe}, \mathrm{Zn}$ & 0.2 & 0.5 & 1.0 \\
$\mathrm{Ca}$ & 1.0 & 3.0 & 5.0 \\
$\mathrm{Mg}$ & 0.5 & 0.8 & 1.2 \\
\hline
\end{tabular}

\section{Bioaccessibility evaluation}

The procedure used for the determination of the bioaccessibility of the analytes was carried out in accordance with the methodology described by Glahn et al. [30]. Here, it was not employed the standardized method proposed by Minekus et al. [26] because $\mathrm{Ca}$ and $\mathrm{Mg}$ are present in large amounts in the reagents used to simulate the in vitro gastrointestinal digestion and then it becomes difficult to determine the small amount of these elements released from the sample to the soluble fraction (hydrolysate). For the gastric digestion simulation, the gastric juice was prepared by mixing $0.20 \mathrm{~g}$ of pepsin and $8 \mathrm{~mL}$ of $0.1 \mathrm{~mol} \mathrm{~L}^{-1} \mathrm{HCl}$, which was shaken for complete pepsin dissolution; for the intestinal digestion simulation, the intestinal juice was prepared by mixing $0.05 \mathrm{~g}$ of pancreatin, $0.30 \mathrm{~g}$ of bile extract and $25 \mathrm{~mL}$ of $0.1 \mathrm{~mol} \mathrm{~L}^{-1} \mathrm{NaHCO}_{3}$ and then this mixture was shaken in order to obtain the complete dissolution.

The bioaccessibility study was performed using $1.0 \mathrm{~g}$ of each milk beverage sample. For the in vitro gastric digestion procedure the $\mathrm{pH}$ of the sample was adjusted to approximately 2 by gradual addition of $5.0 \mathrm{~mol} \mathrm{~L}^{-1} \mathrm{HCl}$ solution, and then $0.50 \mathrm{~mL}$ of the pepsin solution $(0.0125 \mathrm{~g}$ of pepsin/mL sample) were added. This mixture was submitted to a temperature of $37 \pm 3{ }^{\circ} \mathrm{C}$ for 60 minutes in a water bath, under constant stirring. Afterwards, the mixture resulted from the in vitro gastric digestion was submitted to the in vitro intestinal digestion procedure, in which the $\mathrm{pH}$ was adjusted to 6 by gradual addition of $1.0 \mathrm{~mol} \mathrm{~L}^{-1}$ $\mathrm{NaHCO}_{3}$ solution. To this mixture $2.50 \mathrm{~mL}$ of bile-pancreatin solution $(0.005 \mathrm{~g}$ of pancreatin $+0.03 \mathrm{~g}$ of bile/mL of the sample) were added and the solution was again heated at $37 \pm 3{ }^{\circ} \mathrm{C}$ using a water bath for $2 \mathrm{~h}$ under stirring. After the intestinal digestion, the solution was then subjected to an ice bath for 10 minutes, in order to stop the enzymatic action. Moreover, the $\mathrm{pH}$ was adjusted to 7.2 by gradual addition of $0.5 \mathrm{~mol}$ $\mathrm{L}^{-1} \mathrm{NaOH}$ solution and the mixture was centrifuged at $3500 \mathrm{rpm}$ for 30 minutes. The supernatant (chyme) was separated from the precipitate and the soluble analytes in were quantified by ICP OES.

\section{RESULTS AND DISCUSSION Quantification of the analytes}

For the quantification of the total concentration the limits of quantification (LOQ) [31], calculated as $10 \mathrm{\sigma}$ under the established experimental conditions were $0.01 \mathrm{mg} \mathrm{kg}^{-1}$ for $\mathrm{Cu}$ and $\mathrm{Mn}, 0.1 \mathrm{mg} \mathrm{kg}^{-1}$ for Mo, Co and $\mathrm{Mg}, 0.04 \mathrm{mg} \mathrm{kg}^{-1}$ for $\mathrm{Zn}$ and $\mathrm{Fe}$, and $0.3 \mathrm{mg} \mathrm{kg}^{-1}$ for $\mathrm{Ca}$. Therefore, these limits were adequate to determine the concentrations of the elements investigated.

In order to evaluate the sample preparation using microwave-assisted digestion, the MD1 sample was spiked with three different concentration levels of the analytes. The recovery values are presented in Table III. 
Table III. Recovery and RSD values (\%) obtained for the concentration levels added to MD1 sample

\begin{tabular}{cccc}
\hline Elements & Level $\mathbf{1}$ & Level $\mathbf{2}$ & Level 3 \\
\hline $\mathrm{Cu}$ & $101(3)$ & $105(3)$ & $113(8)$ \\
$\mathrm{Mo}$ & $100(7)$ & $100(6)$ & $100(10)$ \\
$\mathrm{Co}$ & $95(4)$ & $97(4)$ & $98(8)$ \\
$\mathrm{Mn}$ & $92(3)$ & $95(3)$ & $100(8)$ \\
$\mathrm{Zn}$ & $82(5)$ & $91(3)$ & $90(4)$ \\
$\mathrm{Fe}$ & $105(5)$ & $96(8)$ & $108(3)$ \\
$\mathrm{Ca}$ & $113(6)$ & $90(5)$ & $93(5)$ \\
$\mathrm{Mg}$ & $106(5)$ & $96(5)$ & $96(5)$ \\
\hline
\end{tabular}

As can be seen, recoveries between 90 and $110 \%$ and RSD lower than $10 \%$ were obtained for all analytes, showing that the proposed sample treatment is adequate for the analysis. In Table IV are presented the concentrations $\left(\mathrm{mg} \mathrm{kg}^{-1}\right)$ for each analyte in the samples and the respective standard deviations. The labels of the samples only contain the values for total concentration of $\mathrm{Ca}$ and the values found here agree with that declared by the manufacturers.

Calcium was the element found in highest concentration, varying over the range of 552 to $1380 \mathrm{mg} \mathrm{kg}^{-1}$, while Co was the only element that was below the $L O Q$ in all samples analyzed.

Table IV. Concentration $\left(\mathrm{mg} \mathrm{kg}^{-1}\right)$ of the elements determined in the samples and the RSD values (\%)

\begin{tabular}{|c|c|c|c|c|c|}
\hline \multirow{3}{*}{ Elements } & \multicolumn{5}{|c|}{ Producer and samples } \\
\hline & \multicolumn{2}{|c|}{ A } & \multicolumn{2}{|c|}{ B } & \multirow{2}{*}{$\begin{array}{c}\text { C } \\
\text { MD5 }\end{array}$} \\
\hline & MD1 & MD2 & MD3 & MD4 & \\
\hline $\mathrm{Cu}$ & $0.60(2)$ & $0.23(3)$ & $<0.001$ & $0.47(4)$ & $<0.001$ \\
\hline Mo & $0.05(0.4)$ & $0.05(1)$ & $<0.01$ & $<0.01$ & $<0.01$ \\
\hline Co & $<0.01$ & $<0.01$ & $<0.01$ & $<0.01$ & $<0.01$ \\
\hline $\mathrm{Mn}$ & $0.84(2)$ & $1.43(4)$ & $<0.001$ & $0.67(2)$ & $<0.001$ \\
\hline $\mathrm{Zn}$ & $3.67(3)$ & $4.18(2)$ & $3.23(1)$ & $2.40(2)$ & $3.01(10)$ \\
\hline $\mathrm{Fe}$ & $7.58(0.3)$ & $5.14(1)$ & $0.56(5)$ & $9.42(0.1)$ & $1.08(5)$ \\
\hline $\mathrm{Ca}$ & $841(5)$ & $1337(2)$ & $1380(8)$ & $674(8)$ & $991(2)$ \\
\hline $\mathrm{Mg}$ & $143(5)$ & $150(3)$ & $98.8(2)$ & $159(4)$ & $97.8(10)$ \\
\hline \multirow{3}{*}{ Elements } & \multicolumn{5}{|c|}{ Producer and samples } \\
\hline & \multicolumn{2}{|c|}{ D } & $\mathbf{E}$ & $\mathbf{F}$ & G \\
\hline & MD6 & MD7 & MD8 & MD9 & MD10 \\
\hline $\mathrm{Cu}$ & $<0.001$ & $<0.001$ & $<0.001$ & $0.45(5)$ & $<0.001$ \\
\hline Mo & $<0.01$ & $<0.01$ & $<0.01$ & $<0.01$ & $<0.01$ \\
\hline Co & $<0.01$ & $<0.01$ & $<0.01$ & $<0.01$ & $<0.01$ \\
\hline $\mathrm{Mn}$ & $<0.001$ & $<0.001$ & $0.11(8)$ & $0.58(2)$ & $<0.001$ \\
\hline $\mathrm{Zn}$ & $2.43(0.3)$ & $2.50(8)$ & $1.68(2)$ & $1.73(5)$ & $2.79(10)$ \\
\hline $\mathrm{Fe}$ & $1.00(7)$ & $0.44(5)$ & $0.83(35)$ & $6.58(6)$ & $1.92(1)$ \\
\hline $\mathrm{Ca}$ & $995(1)$ & $1016(9)$ & $628(5)$ & $552(2)$ & $998.83(2)$ \\
\hline $\mathrm{Mg}$ & $90.3(6)$ & $91.5(6)$ & $70.7(4)$ & $148(10)$ & $105(1)$ \\
\hline
\end{tabular}




\section{Article}

\section{Bioaccessibility of the analytes}

The bioaccessibility represents the soluble fraction which is the amount that can be absorbed and transformed into a biologically active form in the human body. Thus, the knowledge of this amount is more informative than knowing only the total concentration of the element in any food [32]. Table $V$ shows the bioaccessible fraction (bioaccessibility) of the analytes in the samples, which is expressed as percentage, whose results were obtained on the basis of the total concentration shown in Table IV.

Table V. Bioacessible fractions of gastro-intestinal digestion (as percentage of total concentration) and RSDs (\%)

\begin{tabular}{|c|c|c|c|c|c|}
\hline \multirow{2}{*}{ Elements } & \multicolumn{5}{|c|}{ Samples } \\
\hline & MD1 & MD2 & MD3 & MD4 & MD5 \\
\hline $\mathrm{Cu}$ & $41.08(0.04)$ & $63.90(0.04)$ & $<0.001$ & $52.05(0.04)$ & $<0.001$ \\
\hline $\mathrm{Mn}$ & $40.42(0.04)$ & $41.2(0.3)$ & $<0.001$ & $40.15(0.05)$ & $<0.001$ \\
\hline $\mathrm{Zn}$ & $31.4(0.6)$ & $29.5(0.9)$ & $49.0(0.1)$ & $24.6(0.3)$ & $65.4(0.3)$ \\
\hline $\mathrm{Fe}$ & $8(2)$ & $41(2)$ & $43(1)$ & $10(7)$ & $56.8(0.6)$ \\
\hline $\mathrm{Ca}$ & $108(5)$ & $73(4)$ & $94(1)$ & $54(8)$ & $100(2)$ \\
\hline $\mathrm{Mg}$ & $113(5)$ & $99(2)$ & $99(5)$ & $85(5)$ & $105(10)$ \\
\hline \multirow{2}{*}{ Elements } & \multicolumn{5}{|c|}{ Samples } \\
\hline & MD6 & MD7 & MD8 & MD9 & MD10 \\
\hline $\mathrm{Cu}$ & $<0.001$ & $<0.001$ & $<0.001$ & $65.15(0.03)$ & $<0.001$ \\
\hline $\mathrm{Mn}$ & $<0.001$ & $<0.001$ & $<0.001$ & $60.99(0.02)$ & $<0.001$ \\
\hline $\mathrm{Zn}$ & $57.1(0.2)$ & $51.7(0.8)$ & $69.9(0.4)$ & $44.3(0.6)$ & $60.5(0.5)$ \\
\hline $\mathrm{Fe}$ & $22.7(4)$ & $28(1)$ & $44(2)$ & $22(4)$ & $10(3)$ \\
\hline $\mathrm{Ca}$ & $87(2)$ & $85(2)$ & $99(9)$ & $97(2)$ & $92(4)$ \\
\hline $\mathrm{Mg}$ & $97(6)$ & $91(2)$ & $105(4)$ & $102(1)$ & $97(4)$ \\
\hline
\end{tabular}

Molybdenum and Co bioaccessible fractions were not calculated because the concentration for these elements was below the LOQ. The total concentration of Mn in the MD1 sample was $0.84 \mathrm{mg} \mathrm{kg}^{-1}$, but only $0.34 \mathrm{mg} \mathrm{kg}^{-1}$ became soluble, i.e., $40.4 \%$ of the total amount of this nutrient is available for absorption by intestinal cells. Considering all the samples analyzed the bioaccessibility for manganese changes from 40 to $61 \%$. There are no reports concerning the bioaccessibility of this element in dairy beverages. However, it is possible to compare this result with those obtained by do Nascimento da Silva et al. for $\mathrm{Mn}$ in milkbased instant cereals (19-42\%) [16]. It is reasonable that for some milk-based drinks the bioaccessibility values are greater than for instant cereals because the presence of larger amount of proteins in dairy beverages leads to higher Mn solubility. In the present work it was also observed that the Mn bioaccessible fraction increases when its total concentration decreases, as already reported by Velasco-Reynold et al., who indicated that the higher the total Mn intake, the lower the absorption efficiency of the element. In the present work, the same correlation was also observed for $\mathrm{Cu}$ [32].

Nascimento et al. observed that $83 \%$ of $\mathrm{Cu}$ and $78 \%$ of Fe present in cashew nuts were extracted during sample digestion [33]. Considering the milk-based drinks, the average availability of $\mathrm{Cu}$ and $\mathrm{Fe}$ was about 56 and $29 \%$, respectively, which are much smaller values compared to the cashew nuts. Copper absorption inhibitors are sugars, proteins of animal origin, S-amino acids and histidine, therefore the $\mathrm{Cu}$ availability in dairy beverages is lower than in cashew nuts $[13,34,35]$. On the other hand, the values obtained here are in agreement with that obtained by do Nascimento da Silva et al. for $\mathrm{Cu}$ in milk-based instant cereals $(\sim 52 \%)$ and infant formulas (59-67\%) [16]. Moreover, the presence of milk-derived caseino-phospho-peptides 
(CPPs) in dairy samples may cause a great decrease of Fe bioaccessibility as can be seen for milk-based instant cereals (2.4-5\%) and infant formulas (63-69\%) [36]. However, a comparison of bioaccessible fraction obtained for dairy beverages with those obtained by other authors for different samples is not simple, since the bioaccessibility of elements depends on the sample composition, the total amount of each analyte and also the in vitro digestion procedure used.

Calcium and $\mathrm{Mg}$ were the elements which present the highest bioaccessibility values, around $100 \%$, showing that milk-based drinks are a rich source of these elements, because this type of matrix has proteins that provide the increase on the solubility of these elements. Polyphenols and phytates, who could decrease the bioaccessibility of $\mathrm{Ca}$ an $\mathrm{Mg}$ are not present in high concentrations in milk-based drinks [34]. On the other hand, for some samples the values for Zn bioaccessibility (24-69\%) are generally lower due to the presence of casein and casein phosphopeptides which make $\mathrm{Zn}$ insoluble. Although in the acid medium of the stomach, dietary $\mathrm{Zn}$ can be released from casein, a considerable proportion of this casein is not digested, making $\mathrm{Zn}$ less bioaccessible [35,36].

It was possible to observe here that many parameters should influence the nutrient solubility during gastrointestinal digestion, such as the composition of the food, food structure and the in vitro digestion procedure used. Despite it was possible to obtain an approach of the solubility of some elements from milkbased drinks during the gastrointestinal digestion, it is worth highlighting that the actual percentage of each element to be absorbed by the digestive tract will mainly depend on the conditions of each individual. However, some important information concerning the bioaccessibility of inorganic nutrients in dairy beverages was obtained in the present work.

\section{CONCLUSION}

The microwave-assisted digestion using nitric acid and hydrogen peroxide showed to be suitable for the sample treatment, showing recovery values in the range of $90-110 \%$ and RSD less than $10 \%$ for all the elements studied. Calcium was the element with the highest concentration in all beverages evaluated in this study and the values obtained agreed with those declared by the manufacturers.

The in vitro gastrointestinal digestion procedure provided an evaluation of the amount of the analytes that can potentially be absorbed by the body. It was verified that the bioaccessible fractions for $\mathrm{Mn}$ and $\mathrm{Cu}$ decrease with the increase of their total concentration, while $\mathrm{Ca}$ and $\mathrm{Mg}$ showed to be almost fully bioaccessible. The bioaccessibility of these elements may vary with the samples, according to their composition, showing the importance of determining accurately the amount of an essential element is actually available to the human body.

Manuscript received March 27, 2018; revised manuscript received July 9, 2018; accepted July 11, 2018; published online October 3, 2018. 


\section{REFERENCES}

1. MAPA (Ministério da Agricultura, Pecuária e Abastecimento - Brasil), Diário Oficial da União, ISSN 1677-7042, Instrução normativa nำ16, de 23 de agosto de 2005.

2. Ryan, M. P.; Walsh, G. Rev Environ Sci Bio/Technol. 2016, 15 pp 479-498.

3. Teixeira, L. V.; Fonseca, L. M. Arq. Brasil. Medic. Veter. Zootec. 2008, 60, pp 243-250 (DOI: 10.1590/S0102-09352008000100033).

4. http://dairyprocessinghandbook.com/chapter/whey-processing [Accessed 25 January 2018].

5. Révillion, J. P.; Brandelli, A.; Ayub, M. A. S. Cienc. Tecnol. Alim. 2000, 20, pp 246-249 (DOI: 10.1590/S0101-20612000000200020).

6. Almeida, K. E.; Bonassi, I. A.; Roça, R. O. Cienc. Tecnol. Aliment. 2001, 21, pp 187-192 (DOI: 10.1590/S0101-20612001000200012).

7. Santos, C. T.; Marques, G. M. R.; Fontan, G. C. R.; Fontan, R. C. I.; Bonomo, R. C. F.; Bonomo, P. Rev. Brasil. Prod. Agroindust. 2006, 8, pp 111-116 (DOI: 10.15871/1517-8595/rbpa.v8n2p111-116).

8. Pflanzer, S. B.; Cruz, A. G.; Hatanaka, C. L.; Mamede, P. L.; Cadena, R.; Faria, J. A. F.; Silva, A. A. P. Cienc. Tecnol. Alim. 2010, 30, pp 391-398 (DOI: 10.1590/S0101-20612010000200016).

9. Ljung, K.; Palm, B.; Grandér, M.; Vahter, M. Food Chem. 2011, 127, pp 943-951 (DOI: 10.1016/j.foodchem.2011.01.062).

10. Cozzolino, S. M. Biodisponibilidade de Nutrientes, $2^{\text {nd }}$ ed. Barueri: Manole, 2007.

11. Fernández-García, E.; Carvajal-Lérida, I.; Pérez-Gálvez, A. Nutr. Res. 2009, 29, pp 751-760 (DOI: 10.1016/j.nutres.2009.09.016).

12. Gonzalez, R. D.; Romaris-Hortas, V.; Garcia-Sartal, C.; Moreda-Pineiro, A.; Barciela-Alonso, M. D. C.; Bermejo-Barrera, P. Talanta 2010, 82, pp 1668-1673 (DOI: 10.1016/j.talanta.2010.07.043).

13. Khouzam, R. B.; Pohl, P.; Lobinski, R. Talanta 2011, 86, pp 425-428 (DOI: 10.1016/j.talanta.2011.08.049).

14. U.S. Food and Drug Administration (FDA) - CFR - Code of Federal Regulations Title 21 - Food and Drugs, Chapter I - FDA Department of Health and Human Services, Subchapter on Drugs For Human Use. Title 21, Vol 5, Revised as of August 14, 2017.

http://www.accessdata.fda.gov/scripts/cdrh/cfdocs/cfcfr/CFRSearch.cfm?fr=320.1 [Accessed 23 January 2018].

15. do Nascimento da Silva, E.; Leme, A. B.; Cidade, M.; Cadore, S. Talanta 2013, 117, pp 184-188 (DOI: 10.1016/j.talanta.2013.09.008).

16. do Nascimento da Silva, E.; Farias, L. O.; Cadore, S. J. Food. Comp. Anal. 2017, Article in Press. (DOI: 10.1016/j.jfca.2017.06.007).

17. do Nascimento da Silva, E.; Heerdt, G.; Cidade, M.; Pereira, C. D.; Morgon, N. H.; Cadore, S. Microchem. J. 2015, 119, pp152-158 (DOI: 10.1016/j.microc.2014.12.002).

18. do Nascimento da Silva, E.; Aureli, F.; D'Amato, M.; Raggi, A.; Cadore, S.; Cubadda, F. J. Agricult. Food. Chem. 2017, 65, pp 3031-3038 (DOI: 10.1021/acs.jafc.7b01188).

19. Ramos, A.; Cabrera, M. C.; Saadoun, A. Meat Sci. 2012, 91, pp 116-124 (DOI: 10.1016/j.meatsci.2012.01.00).

20. Szymczycha-Madeja, A.; Welna, M.; Pohl, P. J. Brazil. Chem. Soc. 2015, 26, pp 1781-1789 (DOI: 10.5935/0103-5053.20150154).

21. Pereira, C. C.; do Nascimento da Silva, E.; de Souza, A. O.; Vieira, M. A.; Ribeiro, A. S.; Cadore, S. J. Food. Comp. Anal. 2016, Article in Press (DOI: 10.1016/j.jfca.2016.12.001).

22. Ayala-Bribiesca, E.; Turgeon, S. L.; Britten, M. J. Dairy Sci. 2017, 100, pp 2454-2470 (DOI: 10.3168/jds.2016-11902). 
23. Lamothe, S.; Rémillard, N.; Tremblay, J.; Britten, M. Food Res. Int. 2017, 92, pp 138-146 (DOI: 10.1016/j.foodres.2016).

24. Rinaldi, L.; Gauthier, S. F.; Britten, M.; Turgeon, S. L. LWT - Food Sci. Technol. 2014, 57, pp 99-105 (DOI: 10.1016/j.Iwt.2014.01.026).

25. Mulet-Cabero, A.; Rigby, N. M.; Brodkorb, A.; Mackie, A. R. Food Hydrocol. 2017, 67, pp 63-73 (DOI: 10.1016/j.foodhyd.2016.12.039).

26. Minekus, M.; Alminger, M.; Alvito, P.; Ballance, S.; Bohn, T.; Bourlieu, C.; Carrière, F.; Boutrou, R.; Corredig, M.; Dupont, D.; Dufour, C.; Egger, L.; Golding, M.; Karakaya, S.; Kirkhus, B.; Le Feunteun, S.; Lesmes, U.; Macierzanka, A.; Mackie, A.; Marze, S.; McClements, D. J.; Ménard, O.; Recio, I.; Santos, C. N.; Singh, R. P.; Vegarud, G. E.; Wickham, M. S. J.; Weitschies, W., Brodkorb, A. Food and Funct. 2014, 5, pp 1113-1124 (DOI: 10.1039/c3fo60702j).

27. Hur, S. J.; Lim, B. O.; Decker, E. A.; McClements, D. J. Food Chem. 2011, 125, pp 1-12 (DOI: 10.1016/j.foodchem.2010.08.036).

28. Peixoto, R. R. A.; Devesa, V.; Vélez, D.; Cervera, M. L.; Cadore, S. J. Food Comp. Anal. 2016, 48, pp 41-47 (DOI: 10.1016/j.jfca.2016.02.002).

29. Ekmekcioglu, C. Food Chem. 2002, 76, pp 225-230 (DOI: 10.1016/S0308-8146(01)00291-6).

30. Glahn, R. P.; Lee, O. A.; Yeung, A.; Goldman, M. I.; Miller, D. D. J. Nutr. 1998, 128, pp 1555-1561 (DOI: 10.1093/jn/128.9.1555).

31. Thomsen, V.; Schatzlein, D.; Mercuro, D. Spectroscopy 2003, 18, pp 112-114.

32. Velasco-Ryenold, C.; Navarro-Alarcón, M.; De La Serrana, H. L. G.; Perez-Valero, V.; LopezMartinez, M. C. Food Chem. 2008, 109, pp 113-121 (DOI: 10.1016/j.foodchem.2007.12.025).

33. Nascimento, A. N.; Naozuka, J.; Oliveira, P. V. Microchem. J. 2010, 96, pp 58-63 (DOI: 10.1016/j.microc.2010.01.016).

34. Vitali, D.; Vedrina Dragojevic, I.; Sebecic, B. Food. Chem. 2008, 110, pp 62-68 (DOI: 10.1016/j.foodchem.2008.01.056).

35. Mesías, M.; Seiquer, I.; Navarro, M. P. Food Res. Int. 2012, 45, pp 184-190 (DOI: 10.1016/j.foodres.2011.09.030).

36. Pabon, M. L.; Lonnerdal, B. J. Trace Elem. Med. Biol. 2000, 14, 46-153 (DOI: 10.1016/S0946-672X(00)80003-6). 